\title{
Worldwide trend of atmospheric mercury since 1995
}

\author{
F. Slemr ${ }^{1}$, E.-G. Brunke ${ }^{2}$, R. Ebinghaus ${ }^{3}$, and J. Kuss ${ }^{4}$ \\ ${ }^{1}$ Max-Planck-Institut für Chemie, P.O. Box 3060, 55020 Mainz, Germany \\ ${ }^{2}$ South African Weather Service c/o CSIR, P.O. Box 320, Stellenbosch 7599, South Africa \\ ${ }^{3}$ GKSS Forschungszentrum Geesthacht GmbH, Max-Planck-Strasse, 21502 Geesthacht, Germany \\ ${ }^{4}$ Leibniz Institute for Baltic Sea Research, Seestrasse 15, 18119 Rostock-Warnemünde, Germany
}

Received: 8 January 2011 - Published in Atmos. Chem. Phys. Discuss.: 21 January 2011

Revised: 29 April 2011 - Accepted: 11 May 2011 - Published: 23 May 2011

\begin{abstract}
Concern about the adverse effects of mercury on human health and ecosystems has led to tightening emission controls since the mid 1980s. But the resulting mercury emissions reductions in many parts of the world are believed to be offset or even surpassed by the increasing emissions in rapidly industrializing countries. Consequently, concentrations of atmospheric mercury are expected to remain roughly constant. Here we show that the worldwide atmospheric mercury concentrations have decreased by about 20 to $38 \%$ since 1996 as indicated by long-term monitoring at stations in the Southern and Northern Hemispheres combined with intermittent measurements of latitudinal distribution over the Atlantic Ocean. The total reduction of the atmospheric mercury burden of this magnitude within 14 years is unusually large among most atmospheric trace gases and is at odds with the current mercury emission inventories with nearly constant anthropogenic emissions over this period. This suggests a major shift in the biogeochemical cycle of mercury including oceans and soil reservoirs. Decreasing reemissions from the legacy of historical mercury emissions are the most likely explanation for this decline since the hypothesis of an accelerated oxidation rate of elemental mercury in the atmosphere is not supported by the observed trends of other trace gases. Acidification of oceans, climate change, excess nutrient input and pollution may also contribute by their impact on the biogeochemistry of ocean and soils. Consequently, models of the atmospheric mercury cycle have to include soil and ocean mercury pools and their dynamics to be able to make projections of future trends.
\end{abstract}

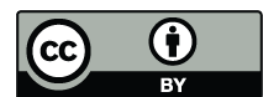

Correspondence to: F. Slemr (franz.slemr@mpic.de)

\section{Introduction}

Gaseous elemental mercury has an atmospheric lifetime of about $1 \mathrm{yr}$ and is thus transported within a hemisphere and even globally (Lindberg et al., 2007). Consequently, mercury can be deposited after its oxidation to less volatile and more soluble compounds in areas far away from where it was originally emitted. Part of the deposited mercury is then transformed to highly toxic methyl mercury which bioaccumulates in the aquatic food chain and, at its end, reaches concentrations which are adverse to human health and ecosystems (Mergler et al., 2007; Scheuhammer et al., 2007). Because of these concerns, mercury emissions of developed countries have been substantially reduced by control measures introduced in the late 1980s (Pirrone et al., 2009). However, as the emissions due to the rapid industrialization in many parts of the world offset the reductions (Streets et al., 2009; Pacyna et al., 2010), a constant or even slightly increasing mercury concentration in the air is expected.

Mercury concentrations in air and wet deposition have been monitored since 1995 at an increasing number of sites in the Northern Hemisphere (Slemr et al., 2003; Temme et al., 2007; Prestbo and Gay, 2009; Cole and Steffen, 2010) but only at one site in the Southern Hemisphere (Slemr et al., 2008). At a majority of sites with records long enough to establish significant trends, ambient mercury concentrations and wet deposition of mercury decreased with time. Recently, Ebinghaus et al. (2011) analysed the baseline mercury concentrations of mercury measured since 1996 at Mace Head, Ireland, and found a downward trend of $0.028 \pm 0.010 \mathrm{ng} \mathrm{m}^{-3} \mathrm{yr}^{-1}$, representing a decrease of $1.6-2.0 \%$ per year. A somewhat smaller downward trend of $0.015 \pm 0.003 \mathrm{ng} \mathrm{m}^{-3} \mathrm{yr}^{-1}$ was observed at Cape Point, South Africa, between 1996 and 2004 taking all data without baseline selection (Slemr et al., 2008), representing a decrease of $1.0-1.5 \%$ per year. Assuming these trends to be representative of the respective hemisphere, which is

Published by Copernicus Publications on behalf of the European Geosciences Union. 
not unreasonable given the atmospheric mercury lifetime of about $1 \mathrm{yr}$ (Lindberg et al., 2007) and an intrahemispheric mixing time of about 3 months (Warneck, 1988), trends of this magnitude would accumulate to a decrease of 15-30\% of the atmospheric mercury burden over a period of 15 years. A decrease of this magnitude is not consistent with the inventories of anthropogenic emissions which are considered to be constant within $\pm 10 \%$ (Streets et al., 2009; Pacyna et al., 2010). Taking into account that anthropogenic emissions represent only about one third of all mercury emissions, with emissions from ocean and soil accounting for the other two thirds (Selin et al., 2007), such decrease would imply that the inventories are wrong by $40-90 \%$. As their quoted uncertainty is only $25-30 \%$ (Streets et al., 2009; Pacyna et al., 2010), other processes have to take part in the observed trend.

Here we present new data obtained at Cape Point since March 2007 and onboard ships over the Atlantic Ocean in 2008 and 2009. By a combination of these recent data with the older data we will show that mercury is quite evenly distributed in the Southern Hemisphere and thus the trend observed at Cape Point can be considered to be representative for it. In the Northern Hemisphere, the trend displayed by baseline mercury measurements at Mace Head is substantially smaller than the one suggested by measurements onboard ships, but it is still large and negative. Comparable negative trends of atmospheric mercury concentrations were also reported for most of the stations of the Canadian Mercury Measurement Network (CAMNet) (Temme et al., 2007; Cole and Steffen, 2010) and the mercury concentrations in wet deposition decreased at most sites of mercury wet deposition (MDN) (Prestbo and Gay, 2009). The overall large negative trend of the atmospheric mercury burden is at last discussed in terms of changes in anthropogenic inventories, oxidation capacity, of a legacy of past mercury emissions, and as a possible consequence of global change.

\section{Experimental}

\subsection{Techniques, monitoring sites and cruises}

The Cape Point station ( $\left.34^{\circ} 21^{\prime} \mathrm{S}, 18^{\circ} 29^{\prime} \mathrm{E}\right)$ in South Africa is operated as one of the World Meteorological Organization (WMO) Global Atmosphere Watch (GAW) stations. The station is located at the southern tip of the Cape Peninsula on top of a peak $230 \mathrm{~m}$ a.s.l., ca. $60 \mathrm{~km}$ south of Cape Town. Gaseous mercury was measured there since September 1995 until December 2004 by a manual double amalgamation technique (Slemr et al., 2008). Apart from 1995, 37 173 samples, each taken over a period of $3 \mathrm{~h}$, were taken annually. Since March 2007 gaseous mercury has been continuously monitored by a Tekran analyser (Model 2537A, Tekran Inc., Toronto, Canada), which represents essentially an automated single amalgamation version of the aforementioned technique.
Mace Head, in County Galway on the west coast of Ireland, at $53^{\circ} 20^{\prime} \mathrm{N}, 9^{\circ} 54^{\prime} \mathrm{W}$ is also operated as one of the WMO GAW stations. Gaseous mercury has been continuously measured there since September 1995 using a Tekran instrument (Ebinghaus et al., 2002; 2011).

At Neumayer station in Antarctica, a Tekran analyzer has been operated from 23 December 1999 to 5 February 2001. The station is located at $70^{\circ} 39^{\prime} \mathrm{S}, 80^{\circ} 15^{\prime} \mathrm{W}$, on the Ekströmisen, $8 \mathrm{~km}$ from Atka Bay (Temme et al., 2003a).

Since 1979 gaseous mercury has been measured during 10 ship cruises during the crossings of the Atlantic Ocean from Germany to different ports in Argentina (Buenos Aires, Mar del Plata, Punta Quilla) or Chile (Punta Arenas). Only the RS Meteor in January/February 1979 and RS Polarstern cruises in December/February 1999/2000 and in November 2008 went to the Gulf of Guinea and to Cape Town, respectively. During 6 cruises until 1994, the manual technique used onboard ships was the same as that at Cape Point (Slemr et al., 2008). On average about 100 samples (each over a period of 2-3 h) were taken in each hemisphere (Slemr et al., 2003). The cruises since 1996 were carried out using the automated Tekran analyzer.

The precision of individual measurements made by the Tekran analyzer was \pm 0.05 and $\pm 0.1 \mathrm{ng} \mathrm{m}^{-3}$ with $30 \mathrm{~min}$ (cruise in 1996, Cape Point, Mace Head) and 15 min (cruise in 1999/2000) sampling times, respectively. The cruises in 2008 and 2009 were dedicated to measurements of air-sea fluxes, and the Tekran analyzer was run with a 5 min sampling time and a correspondingly worse precision of about $0.15 \mathrm{ng} \mathrm{m}^{-3}$ of the individual measurement. Averaged over 15 or $30 \mathrm{~min}$ the precisions given above are reached. The Tekran instruments were usually automatically calibrated every $25 \mathrm{~h}$ using the internal permeation source. The permeation rate of the source was in turn calibrated by injections of known mercury amounts from a vapour saturation device. This calibration was made before and after a cruise and approximately every 3 months at the stations (Ebinghaus et al., 2011).

The precision of individual manual measurements at Cape Point, and for ship cruises amounted to $\pm 5.8 \%$. Each manual measurement is calibrated using the injection of a known mercury amount from a vapour saturation device (Slemr et al., 1985). Thus the precision given above includes the precision of the individual calibrations. All concentrations in this paper are given in $\mathrm{ng} \mathrm{m}^{-3}$ (STP) with the standard temperature of $273.16 \mathrm{~K}$ and pressure of $1013 \mathrm{mbar}$.

Gaseous atmospheric mercury consists predominantly of almost insoluble and volatile gaseous elemental mercury (GEM). Less volatile and more soluble gaseous mercury compounds, termed reactive gaseous mercury (RGM) and defined by the analytical procedures for their detection, usually represent only a few percent of the total gaseous mercury concentrations at ground stations (Ebinghaus et al., 2009). Although RGM was found to be transmitted by the inlet tubing under conditions of extremely low humidity and 
low temperature encountered at the Neumayer site in Antarctica (Temme et al., 2003a), this is considered to be an exception. Under humid conditions with inlet tubing and PTFE filter loaded with sea salt (the Tekran instrument is usually run with a 0.2 or $0.45 \mu \mathrm{m}$ PTFE filter to protect the gold collectors and the inner plumbing of the instrument from contamination by aerosols), RGM will not be transmitted to the gold collectors. Thus the measurements at Cape Point, Mace Head and onboard ships are believed to represent only GEM whereas those at Neumayer represent total gaseous mercury (TGM). The difference between TGM and GEM in marine atmospheres is usually only a few percent and thus small in comparison with the trends discussed later (Ebinghaus et al., 2009). The uncertainty in the attribution of the measured species will thus not influence substantially the results of this paper.

\subsection{Comparability of the data}

Ideally we would have continued the manual measurements some time after the installation of the Tekran instrument at Cape Point to validate the continuity of the data. For reasons beyond our control this was not possible and thus we have to assess the comparability of the data until 2004 and since 2007 in a different way. In the context of this paper, the comparability of the data has two aspects: analytical comparability and comparability of data with different temporal coverage.

The manual double amalgamation technique used at Cape Point until 2004 and ship cruises until 1994 took part as laboratory \#12 on an international field intercomparison at Mace Head carried out in 1995 (Ebinghaus et al., 1999). Figure 2 of Ebinghaus et al. (1999) shows an excellent agreement of the average mercury concentration of $1.81 \pm 0.29 \mathrm{ng} \mathrm{m}^{-3}$ of laboratory \#12 with the median of all measurements of $1.80 \mathrm{ng} \mathrm{m}^{-3}(95 \%$ confidence intervals of +0.08 and $-0.09 \mathrm{ng} \mathrm{m}^{-3}$ ) as well as an agreement within $\pm 0.12 \mathrm{ng} \mathrm{m}^{-3}$ with laboratories \#1 (average $1.80 \pm 0.18 \mathrm{ng} \mathrm{m}^{-3}$ ), \#4 (average $1.82 \pm 0.08 \mathrm{ng} \mathrm{m}^{-3}$ ), \#6.2 (average $1.75 \pm 021 \mathrm{ng} \mathrm{m}^{-3}$ ), and \#9 (average $1.69 \pm 0.15 \mathrm{ng} \mathrm{m}^{-3}$ ), which were using the Tekran instrument. In addition, the manual measurements at Cape Point were found to be comparable (within $\pm 0.03 \mathrm{ng} \mathrm{m}^{-3}$ ) with those made with Tekran onboard RV Polarstern in December 1999 and January 2000 when the ship was near Cape Point (Temme et al., 2003b). This demonstrates that both techniques provide comparable results. A generally good agreement of different techniques for measurement of GEM and/or TGM was found in other intercomparisons (Schroeder et al., 1995; Munthe et al., 2001)

Automated measurements by the Tekran instrument provide an almost complete data coverage; time lost by calibration and maintenance of the instrument represents usually only a few percent loss of a given measurement period. Manual collection of some 150 samples at Cape Point per year covers only $450 \mathrm{~h}$, i.e. only about $4.5 \%$ of the year. The coverage disparity is further aggravated by selection of baseline data: a data filter using concentrations of ${ }^{222} \mathrm{Rn}<100 \mathrm{mBq} \mathrm{m}^{-3}$ yielded only $18 \%$ of baseline data (Brunke et al., 2004) which would leave only some 30 manual measurements a year. Table 1 presents the average concentrations and medians of filtered and unfiltered Tekran data at Cape Point for the years 2007-2009. The average of unfiltered data was higher than that of filtered ones by 0.055 , 0.012 and $0.005 \mathrm{ng} \mathrm{m}^{-3}$ in 2007, 2008, and 2009, respectively. The difference is statistically significant in 2007 and 2008 but even then it is small in comparison with the trends discussed later. Consequently, the unfiltered Cape Point data can be used for further evaluation. Table 1 also shows a generally small difference between medians and averages suggesting that the data at Cape Point are nearly normally distributed.

Figure 1 shows the annual medians of the measurements at Cape Point, Mace Head, Neumayer and during the ship cruises and their $95 \%$ confidence intervals (Sachs, 1978). Confidence intervals for manual measurements at Cape Point varied between 0.01 and $0.12 \mathrm{ng} \mathrm{m}^{-3}$, with largest values in 1995,1997 , and 1998, i.e. in years without a complete coverage (Slemr et al., 2008). These years were not considered in the trend calculation. Confidence intervals for the annual medians considered in the trend calculation did not exceed $0.04 \mathrm{ng} \mathrm{m}^{-3}$ and are much smaller than the trends described below. For comparison, the confidence intervals of annual medians of automated measurements at Cape Point were typically $0.01 \mathrm{ng} \mathrm{m}^{-3}$ and did not exceed $0.02 \mathrm{ng} \mathrm{m}^{-3}$. Altogether, we conclude that randomly distributed manual sampling over the whole year provides a good approximation (within a few $0.01 \mathrm{ng} \mathrm{m}^{-3}$ ) of the annual means and medians measured by a continuous instrument.

\section{Results and discussion}

Figure 1 summarizes the data from the Southern and Northern Hemisphere ( $\mathrm{NH}$ and $\mathrm{SH}$ ), respectively. The data from the GAW stations Cape Point (CPT), South Africa, and Mace Head (MH), Ireland, are presented as annual medians to suppress the influence of occasional high mercury concentrations due to episodes of local or regional pollution such as by biomass burning at CPT (Brunke et al., 2001) as well as depletion events (Brunke et al., 2010). The annual medians for MH were calculated from baseline data only (Ebinghaus et al., 2011).

In the SH the land-based measurements at CPT and Neumayer agree well with measurements made during ship cruises over the Southern Atlantic Ocean. The homogeneity of the mercury concentrations in the SH is not surprising given that anthropogenic emissions constitute only a small fraction of all emissions in the SH (Slemr et al., 2008). The SH sources are dominated by oceanic emissions, the import 
Table 1. Average mercury concentrations and medians of all data measured at Cape Point by the continuous technique and data measured at concentrations of ${ }^{222} \mathrm{Rn}<100 \mathrm{mBq} \mathrm{m}^{-3}$. The standard deviations and number of measurements are also given.

\begin{tabular}{lllll}
\hline Year & \multicolumn{2}{c}{$\begin{array}{c}\text { GEM concentrations at } \\
<100 \mathrm{mBq} \mathrm{m}^{-3}\left[\mathrm{ng} \mathrm{m}^{-3}\right]\end{array}$} & \multicolumn{2}{l}{ GEM concentrations, all data } \\
& \multicolumn{1}{c}{ Median } & Average & Median \\
\hline & Average & 0.879 & $0.928 \pm 0.181(13036)$ & 0.935 \\
2007 & $0.873 \pm 0.090(90)$ & 0.948 & $0.933 \pm 0.132(14418)$ & 0.953 \\
2008 & $0.921 \pm 0.106(858)$ & 0.861 & $0.872 \pm 0.139(12958)$ & 0.870 \\
\hline
\end{tabular}

from the $\mathrm{NH}$ and for a few months by emission from biomass burning of which only the last one is confined to certain but still large areas (Slemr et al., 2008).

Altogether, the concentration of gaseous mercury in the $\mathrm{SH}$ decreased from about $1.35 \mathrm{ng} \mathrm{m}^{-3}$ around 1996 to about $0.9 \mathrm{ng} \mathrm{m}^{-3}$ around 2008 . The trend calculated from the least-square fit of the Cape Point data only is $-0.034 \pm 0.005 \mathrm{ng} \mathrm{m}^{-3} \mathrm{yr}^{-1}\left(r^{2}=0.8677, n=10\right)$. The years 1995, 1997, and 1998 were not considered in this calculation because of their uneven seasonal coverage (Slemr et al., 2008). The trend calculated from Cape Point and ship data is with $-0.035 \pm 0.006 \mathrm{ng} \mathrm{m}^{-3} \mathrm{yr}^{-1}\left(r^{2}=0.7439, n=\right.$ 15) comparable. Both trends are substantially larger than $-0.015 \pm 0.003 \mathrm{ng} \mathrm{m}^{-3} \mathrm{yr}^{-1}$ calculated from the manual measurements at Cape Point until 2004 (Slemr et al., 2008). As discussed before, this difference can be explained neither by the different measurement techniques nor by the different data coverage. Figure 1 suggests that the downward trend accelerated in the second half of the measurement period in both hemispheres. Starting from a concentration of about $1.35 \mathrm{ng} \mathrm{m}^{-3}$ around 1996 the trend of $-0.035 \mathrm{ng} \mathrm{m}^{-3} \mathrm{yr}^{-1}$ translates to a decrease of $0.46 \mathrm{ng} \mathrm{m}^{-3}$ in 14 years until 2009 , i.e. a decrease of $34 \%$ since 1996 . No other long-term observations of gaseous mercury concentrations have been reported so far for this time interval in the $\mathrm{SH}$.

The baseline gaseous mercury concentration at MH decreased from about $1.75 \mathrm{ng} \mathrm{m}^{-3}$ in 1996-1999 to about $1.4 \mathrm{ng} \mathrm{m}^{-3}$ in 2009. As shown by composite back attribution plots for MH in Fig. 1 of Ebinghaus et al. (2011), the baseline $\mathrm{MH}$ data are representative for a large area of the Northern Atlantic including Greenland, Canada, and parts of the Arctic Ocean. The data from ship cruises, measured predominantly south of $50^{\circ} \mathrm{N}$, suggest an even larger decrease within this period. Please note that gaseous mercury concentrations of about $1.1 \mathrm{ng} \mathrm{m}^{-3}$ measured over the northern Atlantic Ocean in 2008 and 2009 are smaller than the annual median concentrations observed at CPT in the mid 1990s. Figure 1 of this paper also suggests a larger downward trend after about 2002, in agreement with the observations in the SH. The least-square fit of the baseline annual medians at Mace Head provides a trend of $-0.024 \pm 0.005 \mathrm{ng} \mathrm{m}^{-3} \mathrm{yr}^{-1}\left(r^{2}=\right.$ $0.6398, n=14$ ) for the $1996-2009$ period which is com-

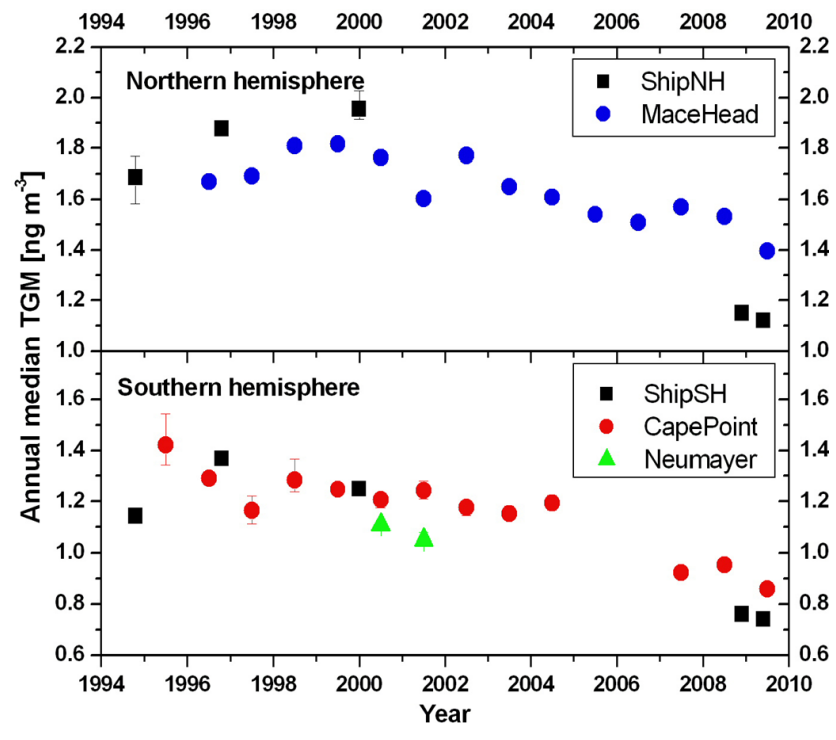

Fig. 1. Trends of GEM concentrations in the Northern and Southern Hemispheres. The points and bars represent the annual medians and the $95 \%$ confidence intervals of the medians, respectively. Mercury was measured by manual double amalgamation technique (see text) at Cape Point until 2004 and during the ship cruise in 1994, all other measurements were made automated technique. The annual medians of automated TGM measurements at Cape Point were calculated using daily mean concentrations. The annual medians at Mace Head were calculated from baseline hourly mean concentrations (Ebinghaus et al., 2010). The median confidence intervals for the continuous measurements are smaller than the symbols.

parable to $-0.028 \pm 0.010 \mathrm{ng} \mathrm{m}^{-3} \mathrm{yr}^{-1}$ calculated from the baseline monthly averages (Ebinghaus et al., 2011). Inclusion of the median concentrations from the ship measurements in 1994-2009 leads to a somewhat larger trend of $-0.035 \pm 0.007 \mathrm{ng} \mathrm{m}^{-3} \mathrm{yr}^{-1}\left(r^{2}=0.5915, n=19\right)$. The least-square fit of the 1994-2009 ship data only is with $-0.051 \pm 0.017 \mathrm{ng} \mathrm{m}^{-3} \mathrm{yr}^{-1}\left(r^{2}=0.7576, n=5\right)$ not significant.

The different trends calculated from the MH data only and from data including the ship measurements point to an inhomogeneous distribution of mercury within the $\mathrm{NH}$. Figure 1 of Slemr et al. (2003) shows this inhomogeneity 
by comparing measurements at several stations in Europe and North America, ranging from the southernmost Wank $\left(48^{\circ} \mathrm{N}\right)$ to northernmost Alert $\left(82^{\circ} \mathrm{N}\right)$. Since 1992 until 2002 mercury concentrations at Wank in Central Europe are substantially higher than those at Mace Head at about the same latitude $\left(53^{\circ} \mathrm{N}\right)$ probably because of the surrounding continental emissions. The concentrations at Mace Head are comparable with those at Lista $\left(58^{\circ} \mathrm{N}\right)$, slightly higher than at Alert and slightly lower than at $\mathrm{Ny}$ Alesund $\left(79^{\circ} \mathrm{N}\right)$. Concentrations measured during the ship cruises are in good agreement with those at Lista and Alert in 1994, in 1996 and 2000. They are slightly higher than at Mace Head but lower than at Wank. A latitudinal gradient cannot be deduced from these data but slightly decreasing concentrations with decreasing latitude starting at about $50^{\circ} \mathrm{N}$ were observed during the ship cruises (Slemr et al., 1985). The latitudinal gradient is most likely due to the emissions which are dominated by anthropogenic sources mostly located between 40 and $60^{\circ} \mathrm{N}$ (Pacyna et al., 2010). The rather narrow spread of the annual medians and the small latitudinal gradient are the result of the short air mixing intrahemispherical time of about 3 months (Warneck, 1988) relative to the tropospheric lifetime of about $1 \mathrm{yr}$ of elemental mercury (Slemr et al., 1985). Despite the differences all stations except the regionally influenced Wank show a similar temporal pattern with mercury levels decreasing between 1993 and 1996 and leveling off thereafter until 2002.

Almost all of the long-term gaseous mercury (CAMNet) and mercury wet deposition (MDN) monitoring sites are also located within the latitude band of $40-60^{\circ} \mathrm{N}$ (Temme et al., 2007; Cole and Steffen, 2010; Prestbo and Gay, 2009). The average downward trend of gaseous mercury concentrations observed on 6 CAMNet sites with a long enough monitoring period (1996-2005) was $0.57 \pm 1.09 \% \mathrm{yr}^{-1}$ with large differences between the individual locations (Temme et al., 2007). The data from Alert did not provide a significant trend for the period 1995-2005 (Temme et al., 2007), but their reanalysis after including the data from 2006 and 2007 also show a decrease of $0.6 \%$ per year $\left(0.0086 \pm 0.0014 \mathrm{ng} \mathrm{m}^{-3} \mathrm{yr}^{-1}\right)$ over a period of 13 years (Cole and Steffen, 2010). This is comparable to the decrease observed at $\mathrm{MH}$. Despite large differences between the $23 \mathrm{MDN}$ sites with significant trends, mercury wet deposition decreased on average by $1.74 \pm 0.74 \% \mathrm{yr}^{-1}$ between 1996 and 2005. Neglecting the possible trends in the distribution of precipitation, this decrease is about three times as large as observed at CAMNet sites and compares well with the trend suggested by the ship measurements over the northern Atlantic Ocean.

Figure 2 shows the NH/SH gaseous mercury concentration ratios over the Atlantic Ocean measured during 10 cruises between 1977 and 2009, and for comparison the ratios of the concentrations at MH to those at CPT (MH baseline annual medians/CPT annual medians). The ratios measured during ship cruises remained with $1.49 \pm 0.10(n=10)$ rather

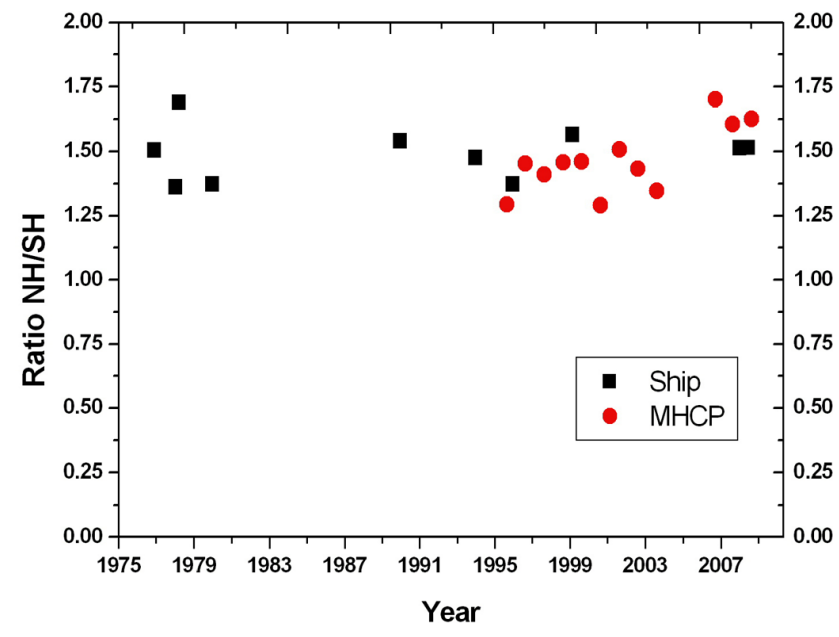

Fig. 2. Ratios of northern to southern hemispheric median concentrations measured over the Atlantic Ocean since 1977 and ratios of annual median concentrations at Mace Head to those at Cape Point.

constant over the last 30 years. The MH/CPT ratios since 1996 are with $1.47 \pm 0.13(n=12)$ comparable. Please note that the seasonal variations of gaseous mercury concentrations in both hemispheres are roughly synchronous (Slemr et al., 2008) making the ratio measured intermittently onboard ships rather insensitive to season. The nearly constant $\mathrm{NH} / \mathrm{SH}$ concentration ratio of 1.48 over such a long period is important since it shows that the distribution of the sources between the two hemispheres has not changed substantially over the last 30 years.

The NH/SH mercury concentration ratio can remain nearly constant only if the relative trends in both hemispheres are nearly equal. We consider the trend in the $\mathrm{SH}$ to be better defined because of the more homogeneous distribution of mercury concentrations. The absolute trend of $-0.035 \pm 0.006 \mathrm{ng} \mathrm{m}^{-3} \mathrm{yr}^{-1}$ in the SH and the initial concentration of about $1.3 \mathrm{ng} \mathrm{m}^{-3}$ at Cape Point in 1996 yield a relative negative trend of $2.7 \%$ per year. The initial concentration at $\mathrm{MH}$ in $1991-1999$ is about $1.75 \mathrm{ng} \mathrm{m}^{-3}$. The relative negative trend of $2.7 \%$ per year would then yield an absolute trend in the $\mathrm{NH}$ of $-0.047 \mathrm{ng} \mathrm{m}^{-3} \mathrm{yr}^{-1}$ which is comparable to the trend suggested by ship measurements only but is substantially larger than the significant trends both from MH data only and from combined $\mathrm{MH}$ and ship data. Based on the initial concentration of $1.75 \mathrm{ng} \mathrm{m}^{-3}$, the relative negative trends calculated from the MH data only and $\mathrm{MH}$ and ship data correspond to 1.4 and $2.0 \%$ per year, respectively.

In summary, there is a strong evidence for a downward trend of tropospheric mercury concentrations within both hemispheres over the past 14 years. Using the CPT, MH and ship data we conclude that the atmospheric mercury burden decreased between 1996 and 2009 with a relative rate somewhere between 1.4 and $2.7 \%$ per year in the $\mathrm{NH}$ and $\mathrm{SH}$, respectively, i.e. by 20 to $38 \%$ since 1996 . Such decrease is 
large for most of the trace gases except for some halocarbons whose emissions are controlled by Montreal Protocol (Clerbaux and Cunnold, 2007). This suggests a substantial shift in the global biogeochemical cycle of mercury. Below we discuss several possible explanations: (a) the decrease of the anthropogenic emissions, (b) the acceleration of the oxidation of mercury in the atmosphere, (c) the decrease of emissions from the legacy of historical mercury use and emissions, and (d) changing emissions from the oceans and the soils due to global change.

The steady-state budgets of atmospheric mercury assume that the primary anthropogenic sources with biomass burning represent only about one third of the total mercury emissions (Selin et al., 2007). The inventories of anthropogenic mercury emissions yield a total anthropogenic emission of about $2000 \mathrm{t} \mathrm{yr}^{-1}$ (uncertainty is assumed to be less than $\pm 30 \%$, Pacyna et al., 2010) which is believed to have changed only by about $\pm 15 \%$ between 1995 and 2006 (from $2128 \mathrm{t} \mathrm{yr}^{-1}$ in 1996 to $2480 \mathrm{t} \mathrm{yr}^{-1}$ in 2006 (Streets et al., 2009) and from $2317 \mathrm{t} \mathrm{yr}^{-1}$ in 1995 to $1930 \mathrm{t} \mathrm{yr}^{-1}$ in 2005, Pacyna et al., 2010). It is obvious that rather small changes in anthropogenic emissions representing only about one third of total emissions cannot explain the observed decrease of the atmospheric mercury burden. The discrepancy would remain substantial even if the anthropogenic emissions were the only mercury emissions, but such assumption would not be consistent with the constant $\mathrm{NH} / \mathrm{SH}$ concentration ratio and the simultaneous $30 \%$ decrease of the atmospheric mercury burden with emissions located and reduced mostly in the NH.

Despite more than 20 years of research on the atmospheric mercury cycle and its crucial importance to mercury cycling in the atmosphere, the oxidation mechanism of gaseous elemental mercury to compounds amenable to removal by dry and wet deposition remains elusive (Lin et al., 2006; Lindberg et al., 2007). Three major pathways are proposed and their importance disputed: reaction of $\mathrm{Hg}^{0}$ with $\mathrm{OH}, \mathrm{O}_{3}$ and $\mathrm{Br} / \mathrm{BrO}$ (Lin et al., 2006; Holmes et al., 2010). $\mathrm{OH}$ is the major oxidant for the majority of atmospheric trace gases and its global increase on the order of $30 \%$ within 14 years would induce large decreasing trends in the concentrations of many long lived substances, such as $\mathrm{CH}_{4}$, which has not been observed (Clerbaux and Cunnold, 2007). In fact, a recent study shows that $\mathrm{OH}$ concentrations remained nearly constant within the period discussed here (Montzka et al., 2011). Ozone concentrations have increased in some regions of the troposphere and decreased in others (Oltmans et al., 2006). Despite the regional trend differences and some inconsistencies in the data (Clerbaux and Cunnold, 2007), an overall increase of tropospheric ozone concentrations on the order of $30 \%$ since 1995 is not supported by the observations. The tropospheric organic bromine reservoir consists to a larger part of long-lived compounds of purely (halones) or partly $\left(\mathrm{CH}_{3} \mathrm{Br}\right)$ anthropogenic origin and to a lesser degree of short-lived compounds mostly of natural origin. The measurements of the latter ones suggest that their emission remains constant (Clerbaux and Cunnold, 2007). Controls imposed by the Montreal Protocol on emissions of halones and anthropogenic emissions of $\mathrm{CH}_{3} \mathrm{Br}$ has led to a peak of stratospheric $\mathrm{BrO}$ concentrations at around 2000 and a slight decrease since (Clerbaux and Cunnold, 2007). In summary, the hypothesis of an accelerating oxidation of elemental mercury in the atmosphere by the amount suggested here is not supported by observations.

The atmospheric mercury burden and mercury deposition are believed to have increased by a factor of $3 \pm 1$ since preindustrial times (Mason and Sheu, 2002; Lindberg et al., 2007). The human activity has also substantially increased the soil and ocean mercury reservoirs and the fluxes between them and the atmosphere (Mason and Sheu, 2002; Lamborg et al., 2002; Fitzgerald and Lamborg, 2003; Strode et al., 2007; Smith-Downey et al., 2010). The atmospheric residence time of about $1 \mathrm{yr}$ is somewhat shorter than the mercury residence time of $1.2-4 \mathrm{yr}$ in the oceanic mixed layer (depending on the assumed mixed layer depth) (Lamborg et al., 2002; Strode et al., 2007) but the mean residence time for water parcels with enhanced mercury concentrations may range from a few decades to more than 2 millennia (Primeau and Holzer, 2006). The residence time of mercury in soils is estimated to be 80-100 yr (Fitzgerald and Lamborg, 2003; Smith-Downey et al., 2010). With nearly constant anthropogenic emissions in the last 15 years (Streets et al., 2009; Pacyna et al., 2010), the atmospheric mercury burden will thus follow the changing emissions from the soil and ocean which partly contain mercury from a legacy of historical anthropogenic mercury pollution (Mason and Sheu, 2002; Fitzgerald and Lamborg, 2003; Smith-Downey et al., 2010). As the historical anthropogenic mercury release into environment is poorly documented, one can only speculate about the past decrease of emissions leading to the observed trend. The phasing out of mercury-containing products and the increasing control of manufacturing processes with mercury involvement started in the late 1980s (Hylander and Meili, 2003) but mercury emissions from coal burning, one of the largest anthropogenic sources, might have started to decrease already in the late 1970s and early 1980s as a corollary of regulations limiting the emissions of other pollutants from coal fired power plants (Pirrone et al., 2009). The sediment, peat, and ice core studies suggest that the mercury deposition peaked between 1950 and 1990 at a majority of sites (Schuster et al., 2002; Biester et al., 2007; Muir et al., 2009; Mast et al., 2010), although it is still increasing at some locations (Fitzgerald et al., 2005). The firn study by Fain et al. (2009) suggests that the mercury concentration in air peaked at around 1970. The decreasing emissions from the legacy of historical mercury use and emissions thus appear to be the most plausible explanation for the observed trend.

Acidification of oceans, climate change, excess nutrient inputs, and pollution are fundamentally changing the ocean biogeochemistry (Doney, 2010) and will certainly also influence mercury ocean-air fluxes. But the extent and even the 
direction of the change in mercury ocean-air fluxes are difficult to predict because many different and partly counteracting processes with poorly known mechanisms have to be taken into account. Shrinking ice cover of the Arctic Ocean is expected to increase penetration of UV radiation and thus enhance the photochemical reduction of $\mathrm{Hg}^{2+}$ to $\mathrm{Hg}^{0}$ and by this the $\mathrm{Hg}$ emission (Outridge etal., 2008). Stratospheric ozone depletion might have the same effect by increasing the UV radiation (IPCC, 2007) but shifting solar radiation to shorter wavelength could also intensify the oxidation of elemental mercury into $\mathrm{Hg}^{2+}$ (Qureshi et al., 2010). Surface ocean warming would reduce nutrient supply by an increased stability of a thinner surface layer but this effect is counteracted by rising coastal nitrogen levels (Doney, 2010) and increased $\mathrm{Fe}$ supply due to enhanced deposition of dust mobilized by more frequent storms. Thus the impact of climate change on microbial activity (Mason et al., 1995) on the $\mathrm{Hg}^{2+}$ to $\mathrm{Hg}^{0}$ reduction and thus on emission is difficult to predict.

Climate change will surely also influence the fluxes between soils and atmosphere. Melting ice and degradation of organic matter in permafrost soils might release mercury deposited long times ago (Outridge et al., 2008). Increase of mercury emissions due to increasing soil surface temperature (e.g. Poissant et al., 2004), however, might be counteracted by reduced soil humidity in many areas (e.g. Song and Van Heyst, 2005). Increasing ozone concentrations and changing turbulence can also influence the mercury emissions from soils (Engle et al., 2005; Poissant et al., 1999).

\section{Conclusions}

The measurements presented here provide strong evidence that the global atmospheric mercury burden has decreased by about $30 \%$ since 1995 . Consequently, the conclusion reached by the Panel on Source Attribution of Atmospheric Mercury (Lindberg et al., 2007) that "there has been no discernible net change in the size of the atmospheric pool of $\mathrm{Hg}$ in the Northern Hemisphere since the mid-1970s" has to be updated.

We have shown that the observed trend can be neither explained by decreasing anthropogenic emissions nor by accelerated oxidation of atmospheric mercury. Changing climate, acidification of the oceans, and legacy of past mercury releases into the environment can all contribute but we believe the legacy of historical mercury release into environment to be the most important. As the response of the atmospheric mercury burden to changing emissions will essentially depend on mercury residence time in soil and ocean reservoirs, we consider soil and oceans to be an essential part of any model trying to predict the response of the atmospheric burden to changing anthropogenic emissions in future. And last but not least: more extensive mercury monitoring especially south of $40-60^{\circ} \mathrm{N}$ is needed to confirm the reported trend of the atmospheric mercury burden and to follow its future development.

Acknowledgements. Our thanks go to a multitude of people who helped to carry out the ship measurements at the RS Walther Herwig and the RS Polarstern and enabled to sustain the long-term TGM measurements at Cape Point and Mace Head. Alistair Manning and Richard Derwent provided the classification of baseline air masses arriving at the Mace Head station. We also thank Chris Holmes for valuable comments on the draft. This work was partly supported by the Deutsche Forschungsgemeinschaft and the Irish Environmental Protection Agency.

The service charges for this open access publication have been covered by the Max Planck Society.

Edited by: A. Pszenny

\section{References}

Biester, H., Bindler, R., Martinez-Cortizas, A., and Engstrom, D.R.: Modeling the past atmospheric deposition of mercury using natural archives, Environ. Sci. Technol. 41, 4851-4860, 2007.

Brunke, E.G., Labuschagne, C., and Slemr, F.: Gaseous Hg emissions from a fire in the Cape Peninsula, South Africa, during January 2000, Geophys. Res. Lett. 28, 1483-1486, 2001.

Brunke, E.-G., Labuschagne, C., Parker, B., Scheel, H. E., and Whittlestone, S.: Baseline air mass selection at Cape Point, South Africa: application of ${ }^{222} \mathrm{Rn}$ and other filter criteria to $\mathrm{CO}_{2}$, Atmos. Environ. 38, 5693-5702, 2004.

Brunke, E.-G., Labuschagne, C., Ebinghaus, R., Kock, H. H., and Slemr, F.: Gaseous elemental mercury depletion events observed at Cape Point during 2007-2008, Atmos. Chem. Phys., 10, 11211131, doi:10.5194/acp-10-1121-2010, 2010.

Clerbaux, C., and Cunnold, D.M.: Long-lived compounds, in: "Scientific Assessment of Ozone Depletion: 2006", WMO, Geneva, 2007.

Cole, A. S. and Steffen, A.: Trends in long-term gaseous mercury observations in the Arctic and effects of temperature and other atmospheric conditions, Atmos. Chem. Phys., 10, 4661-4672, doi:10.5194/acp-10-4661-2010, 2010.

Doney, S. C.: The growing human footprint on coastal and openocean biogeochemistry, Science, 328, 1512-1516, 2010.

Ebinghaus, R., Jennings, S. G., Schroeder, W. H., Berg, T., Donaghy, T., Guentzel, J., Kenny, C., Kock, H. H., Kvietkus, K., Landing, W., Mühleck, T., Munthe, J., Prestbo, E. M., Schneeberger, D., Slemr, F., Sommar, J., Urba, A., Wallschläger, D., and Xiao, Z.: International field intercomparison measurements of atmospheric mercury species at Mace Head, Ireland, Atmos. Environ. 33, 3063-3073, 1999.

Ebinghaus, R., Kock, H. H., Coggins, A. M., Spain, T. G., Jennings, S. G., and Temme, Ch.: Long-term measurements of atmospheric mercury at Mace Head, Irish west coast, between 1995 and 2001, Atmos. Environ. 36, 5267-5276, 2002.

Ebinghaus, R., Banic, C., Beauchamp, S., Jaffe, D., Kock, H. H., Pirrone, N., Poissant, L., Sprovieri, F., and Weiss-Penzias, 
P. S.: Spatial coverage and temporal trends of land-based atmospheric mercury measurements in the northern and southern hemispheres, in: Mercury Fate and Transport in the Global Atmosphere, edited by: Pirrone, N., Mason, R., 223-291, Springer, Dordrecht, The Netherlands, 2009.

Ebinghaus, R., Jennings, S. G., Kock, H. H., Derwent, R. G., Manning, A. J., and Spain, T. G.: Decreasing trend in total gaseous mercury observations in baseline air at Mace Head, Ireland, from 1996 to 2009, Atmos. Environ., 45, 3475-3480, 2011.

Engle, M. A., Gustin, M. S., Lindberg, S. E., Gertler, A. W., and Ariya, P. A.: The influence of ozone on atmospheric emissions of gaseous elemental mercury and reactive gaseous mercury from substrates, Atmos. Environ. 39, 7506-7517, 2005.

Fain, X., Ferrari, C. P., Dommergue, A., Albert, M. R., Battle, M., Severinghaus, J., Arnaud, L., Barnola, J.-M., Cairns, W., Barbante, C., and Boutron, C.: Polar firn air reveals largescale impact of anthropogenic mercury emissions during the 1970s, Proc. Natl. Acad. Sci. U.S.A., 106(38), 16114-16119, doi:10.1073/pnas.0905117106, 2009.

Fitzgerald, W. F. and Lamborg, C. H.: Geochemistry of mercury in the environment, Treatise Geochem. 9, 107-148, 2003.

Fitzgerald, W. F., Engstrom, D. R., Lamborg, C. H., Tseng Ch.M. T., Balcom, P. H., and Hammerschmidt, C. R.: Modern and historic atmospheric mercury fluxes in northern Alaska: Global sources and arctic depletion, Environ. Sci. Technol., 39, 557568, 2005.

Holmes, C. D., Jacob, D. J., Corbitt, E. S., Mao, J., Yang, X., Talbot, R., and Slemr, F.: Global atmospheric model for mercury including oxidation by bromine atoms, Atmos. Chem. Phys., 10, 12037-12057, doi:10.5194/acp-10-12037-2010, 2010.

Hylander, L. D. and Meili, M.: 500 years of mercury production: global annual inventory by region until 2000 and associated emissions, Sci. Total Environ. 304, 13-27, 2003.

IPCC, Climate Change 2007: Synthesis Report, Geneva, Switzerland, 2007.

Lamborg, C. H., Fitzgerald, W. F., O'Donnell, J., and Torgersen, T.: A non-steady-state compartmental model of global-scale mercury biogeochemistry with interhemispheric atmospheric gradients, Geochim. Cosmochim. Acta 66, 1105-1118, 2002.

Lin, C.-J., Pongprueksa, P., Lindberg, S. E., Pehkonen, S. O., Byun, D., and Jang, C.: Scientific uncertainties in atmospheric mercury models I: Model science evaluation, Atmos. Environ. 40, 29112928, 2006.

Lindberg, S., Bullock, R., Ebinghaus, R., Engstrom, D., Feng, X., Fitzgerald, W., Pirrone, N., Prestbo, E., and Seigneur, Ch.: A synthesis of progress and uncertainties in attributing the sources of mercury in deposition, Ambio 36, 19-32, 2007.

Mason, R. P. and Sheu, G.-R.: Role of the ocean in the global mercury cycle, Global Biogeochem. Cycles, 16, 1093, doi:10.1029/2001GB001440, 2002.

Mason, R. P., Morel, F. M. M., and Hemond, H. F.: The role of microorganisms in elemental mercury formation in natural waters, Water Air Soil Pollut. 80, 775-787, 1995.

Mast, A. M., Manthorne, D. J., and Roth, D. A.: Historical deposition of mercury and selected trace elements to high-elevation National Parks in the Western U.S. inferred from lake-sediment cores, Atmos. Eviron. 44, 2577-2586, 2010.

Mergler, D., Anderson, H. A., Chan, L. H. M., Mahaffey, K. R., Murray, M., Sakamoto, M., and Stern, A. H.: Methylmercury exposure and health effects in humans: A worldwide concern, Ambio, 36, 3-11, 2007.

Montzka, S. A., Krol, M., Dlugokencky, E., Hall, B., Jöckel, P., and Lelieveld, J.: Small interannual variability of global atmospheric hydroxyl, Science, 331, 67-69, 2011.

Muir, D. C. G., Wang, X., Yang, F., Nguyen, N., Jackson, T. A., Evans, M. S., Douglas, M., Köck, G., Lamoureux, S., Pienitz, R., Smol, J. P., Vincent, W. F., and Dastoor, A.: Spatial trends and historical deposition of mercury in eastern and northern Canada inferred from lake sediment cores, Environ. Sci. Technol. 43, 4802-4809, 2009.

Munthe, J., Wängberg, I., Pirrone, N., Iverfeldt, A., Ferrara, R., Ebinghaus, R., Feng, X., Gardfeldt, K., Keeler, G., Lanzillotta, E., Lindberg, S. E., Lu, J., Mamane, Y., Prestbo, E., Schmolke, S., Schroeder, W. H., Sommar, J., Sprovieri, F., Stevens, R. K., Stratton, W., Tuncel, G., and Urba, A.: Intercomparison of methods for sampling and analysis of atmospheric mercury species, Atmos. Environ., 35, 3007-3017, 2001.

Oltmans, S. J., Lefohn, A. S., Harris, J. M., Galbally, I., Scheel, H. E., Bodeker, G., Brunke, E., Claude, H., Tarasick, D., Johnson, B. J., Simmonds, P., Shadwick, D., Anlauf, K., Hayden, K., Schmidlin, F., Fuhimoto, T., Akagi, K., Meyer, C., Nichol, S., Davies, J., Redondas, A., and Cuevas, E.: Long-term changes in tropospheric ozone, Atmos. Environ. 40, 3156-3173, 2006.

Outridge, P. M., Macdonald, R. W., Wang, F., Stern, G. A., and Dastoor, A. P.: A mass balance inventory of mercury in the Arctic Ocean, Environ. Chem. 5, 89-111, 2008.

Pacyna, E. G., Pacyna, J. M., Sundseth, K., Munthe, J., Kindbom, K., Wilson, S., Steenhuisen, F., and Maxson, P.: Global emission of mercury to the atmosphere from anthropogenic sources in 2005 and projections to 2020, Atmos. Environ. 44, 2487-2499, 2010.

Pirrone, N., Cinnirella, S., Feng, X., Finkelman, R. B., Friedli, H. R., Leaner, J., Mason, R., Mukherjee, A. B., Stracher, G., Streets, D. G., and Telmer, K.: Global mercury emissions to the atmosphere from natural and anthropogenic sources, in: Mercury Fate and Transport in the Global Atmosphere, edited by: Pirrone, N., Mason, R., 3-49, Springer, Dordrecht, The Netherlands, 2009.

Poissant, L., Pilote, M., and Casimir, A.: Mercury flux measurements in a naturally enriched area: Correlation with environmental conditions during the Nevada Study and Tests of the Release of Mercury from Soils (STORMS), J. Geophys. Res. 104, 21845-21857, 1999.

Poissant, L., Pilote, M., Constant, P., Beauvais, C., Zhang, H.H., and $\mathrm{Xu}, \mathrm{X}$. : Mercury gas exchanges over selected bare soil and flooded sites in the bay St. François wetlands (Québec, Canada), Atmos. Environ. 38, 4205-4214, 2004.

Prestbo, E. M. and Gay, D. A.: Wet deposition of mercury in the U.S. and Canada, 1996-2005: Results and analysis of the NADP mercury deposition network (MDN), Atmos. Environ. 43, 42234233, 2009.

Primeau, F. W. and Holzer, M.: The ocean's memory of the atmosphere: Residence-time and ventilation-rate distributions of water masses, J. Phys. Oceanography 36, 1439-1456, 2006.

Qureshi, A., O’Driscoll, N. J., MacLeod, M., Neuhold, Y.-M., and Hungerbühler, K.: Photoreactions of mercury in surface ocean water: Gross reaction kinetics and possible pathways, Environ. Sci. Technol. 44, 644-649, 2010.

Sachs, L.: Angewandte Statistik, 201 pp., Springer-Verlag, Berlin, 
Germany, 1978.

Scheuhammer, A. M., Meyer, M. W., Sandheinrich, M. B., and Murray, M. W.: Effects of environmental methylmercury on the health of wild bird, mammals, and fish, Ambio, 36, 12-18, 2007.

Schroeder, W. H., Keeler, G., Kock, H., Roussel, P., Schneeberger, D., and Schaedlich, F.: International field intercomparison of atmospheric mercury measurement methods, Water Air Soil Pollut., 80, 611-620, 1995.

Schuster, P. F., Krabbenhoft, D. P., Naftz, D. L., Dewayne Cecil, L., Olson, M. L., Dewild, J. F., Susong, D. D., Green, J. R., and Abbott, M. L.: Atmospheric mercury deposition during the last 270 years: A glacial ice core record of natural and anthropogenic sources, Environ. Sci. Technol. 36, 2303-2310, 2002.

Selin, N. E., Jacob, D. J., Park, R. J., Yantosca, R. M., Strode, S., Jaeglé, L., and Jaffe, D.: Chemical cycling and deposition of atmospheric mercury: Global constraints from observations, J. Geophys. Res., 112, D02308, doi:10.1029/2006JD007450, 2007.

Slemr, F., Schuster, G., and Seiler, W.: Distribution, speciation, and budget of atmospheric mercury, J. Atmos. Chem., 3, 407-434, 1985.

Slemr, F., Brunke, E.-G., Ebinghaus, R., Temme, Ch., Munthe, J., Wängberg, I., Schroeder, W., Steffen, A., and Berg, T.: Worldwide trend of atmospheric mercury since 1977, Geophys. Res. Lett., 30(10), 1516, doi:10.1029/2003GL016954, 2003.

Slemr, F., Brunke, E.-G., Labuschagne, C., and Ebinghaus, R.: Total gaseous mercury concentrations at the Cape Point GAW station and their seasonality, Geophys. Res. Lett., 35, L11807, doi:10.1029/2008GL033741, 2008.
Smith-Downey, N. V., Sunderland, E. M., and Jacob, D. J.: Anthropogenic impacts on global storage and emissions of mercury from terrestrial soils: Insights from a new global model, J. Geophys. Res., 115, G03008, doi:10.1029/2009JG001124, 2010.

Song, X. and Van Heyst, B.: Volatilization of mercury from soils in response to simulated precipitation, Atmos. Environ., 39, 7494 7505.

Streets, D. G., Zhang, Q., and Wu, Y.: Projections of global mercury emissions in 2050. Environ. Sci. Technol., 43, 2983-2988, 2009.

Strode, S. A., Jaeglé, L., Selin, N. E., Jacob, D. J., Park, R. J., Yantoska, R. M., Mason, R. P., and Slemr, F.: Air-sea exchange in the global mercury cycle, Global Biogeochem. Cycles 21, GB1017, doi:10.1029/2006GB002766, 2007.

Temme, C., Einax, J. W., Ebinghaus, R., and Schroeder, W. H.: Measurements of atmospheric mercury species at a coastal site in the Antarctic and over the South Atlantic Ocean during polar summer, Environ. Sci. Technol. 37, 22-31, 2003a.

Temme, C., Slemr, F., Ebinghaus, R., and Einax, J.W.: Distribution of mercury over the Atlantic Ocean in 1996 and 1999-2001, Atmos. Environ. 37, 1889-1897, 2003b.

Temme, C., Blanchard, P., Steffen, A., Banic, C., Beauchamp, S., Poissant, L., Tordon, R., and Wiens, B.: Trend, seasonal and multivariate analysis study of total gaseous mercury data from the Canadian atmospheric mercury measurement network (CAMNet), Atmos. Environ., 41, 5423-5441, 2007.

Warneck, P.: Chemistry of the Natural Atmosphere, Academic Press, San Diego, 17-37, 1988. 